Vox Patrum 6/1986/z.10

\title{
KLER AFRYKAŃSKI W ŚWIETLE SYNODÓW IV I V WIEKU
}

W niniejszym artykule chciałbym przedstawic obraz duohowienstwa katolloklego Afryk1 pómocnej w oparcin o kanony synod6w afrykansk1ch z IV 1 vieku. Zgodnie z tytułem artykułu omórie jedynie kanony synodó afrykarskich, dotyczące dyscypliny kościelnej z pominięciem jednak tych, które maja charakter ozysto dogmatyozny.

Zaraz na wstęp1e pragnę zaznaczyd, 1t synody afrykanskie omawianego okresu miały w więszości charakter dogmatyezny, poniewaz musiały zajnowad stanowisko wobec rodzących sie błę́rw/m.1n. donatýfc1 1 pelagiante/, godzqcych w jedność wielkiego Kośc1oła. Sprawy doktrynalne nie stanow1ły jednak wyłącznego przedmiotu troskí ojców synodalnych, gdyz przy tej okazji zajmowall się on takze sprawami zwizzzanymi z karnościa duchowieństwa 1 licznymi problemami pastoralnymi. Wiele z tych kanonów odnosiło się równtez do kleru. Z nich mozna zaczerpnąé liczne, cenne wiadomoścl, które pozwola ukazać obraz duchowleństwa tamtego okresu 1 lansowany model duszpasterza-kapłana. oraz jego posługl duszpasterskiej dla dobra Kośc1 oła.

\section{SWIBCENIA}

1. P r z y n a 1 e z n o śc d o k 1 e r u. Pod nazwa "kler" rozumiemy tutaj wszystkie stopnie hierarchi1 kościelnej, zaczynając od lektora, a kończąc na biskup1e. Warunkiem przynaleźnośc1 do kleru było ukońozente przynajmniej 25 roku tyoia 1 . Nie mógz

1 Concilium Carthaginiense /a. 419/. Canones in causa Apiar11 19, CCL 149,123: "Et ut ante XXV annos aetate diaconus vel presbyter nullus ordinetur neque virgines consecrentur. Ft ut lectores populum non salutent". 
zostać duchownym człowiek świecki, który poślubił wowę ${ }^{2}$, jak rómniez taki, który powtórnie przyjąz chrzest ${ }^{3}$. Odnośnie zaś do schizmatykó donatystów synody postanawiały, że mogli oni zostać członkami kleru katolickiego jedynie wówczas, gdy do schizmy należell od dzieciństwa, a więc bez własnej winy".

2. Wa r u nk 1 o t $r$ z y m a 1 a ś 1 e c e ń. Przedstawiwszy warunki stawiane osobie świeckiej, by mogła stać się członkiem kleru/a więc osiągnąć przynajmniej stopień lektora/ omówimy teraz te, które są wymagane do otrzymania święceń wyższych.

otóz osoba ubiegająca się o święcenia nie mogła po chrzcie nykonywać zawodu żołniorza ${ }^{5}$, a wszyscy członkowie domu kandydata maJącego przyjąć święcenia musieli należé do Kościoła katolickiego. Przez słowo "dom"/domus/ rozumieć należy wszystkie osoby /zarórno krewnych, jak 1 służbę/, podległe opiece kandydata ${ }^{6}$. Do święceń nie mógł być również dopuszczony clericus alienus, tzn. należący do innej diecezji ${ }^{7}$.

2 Concilium Thelense/a. 418/, 5, CCL 149,61: "Ut is qui laicus viduam duxerit, non admittatur ad clerum".

3 Concilium Carthaginiense /a. 419/. Canones in causa Apiari1 33, CCL 149,127: "Neque permittendum est ut rebaptizati ad clericatus gradum promoveantur".

4 Registri Ecclesiae Carthaginiensis Excerpta 57, CCL 149,195: "[...] ut h11 qui apud Donatistas parvuli baptizati sunt, nondum scire valentes erroris eorum interitum, et posteaquam ad aetatem rationis capacem pervenerunt, agnita veritate, falsitatem eorum abhorrentes, ad ecclesiam Dei catholicam per universum mundum diffusam, ordine antiquo, per manus impositionem recepti sunt, debere talibus suscipiendum munus clericatus non impedire nomen error1s".

5 Concilium Thelense 3, CCL 149,61: "[...] s1 quis post remiss1onem peccatorum cingulum militiae saecularis habuerit, ad clerum admitt1 non debet".

6 Registri Ecclesiae Carthaginiensis Excerpta 36, CCL 149, 184 : "Ut episcopi et presbyteri et diaconi non ordinentur priusquam omnes qui sunt in domo eorum christianos catholicos pecerint".

7 Concilium Thelense 6, CCL 149,61: "ut de aliena ecclesia ordinare clericum nullus usurpet". 
Ponlewaz najbardziej eksponowane miejsce w hierarchil kościelnej zajmował biskup, synody omawianego okresu bardzo często precyzowały warunki potrzebne do osiagnięcia tej godności, wskazując zarómno na eposób wyboru, Jak 1 samych święceń. Odnośnte więc do wyboru kandydata na biskupa dokumenty synodalne ustalały, 1ż wystarozała tu deoyzja Kośc1 oła Matk1, to znaczy tego, od którego kandydat bezpó́rednto zalezal ${ }^{8}$. W przypadku zaś kandydata lałka, kanony stawiały mu warunek przejócia w clągu jednego roku przed przyjęciem święceń b1skuploh przez wszystkie stopnie kościelne 1 praoy duszpasterskiej, konteoznej do nalezytego przygotowania się do przyszłych zadań biskupa ${ }^{9}$. Zaden z nich nie mógł przyją́ ́́więceń biskupich bez zatwierdzen1a metropolity ${ }^{10}$. Nie mógł ich równiez udzielić jeden tylko biskup ${ }^{11}$, ale winno loh byó trzech, wraz z pisemnym pozwoleniem innych biskupów 1 potwierdzeniem metropolity lub prymasa ${ }^{12}$. Przepis ten jednak zostal zmodyfikowany. Wrzypadku naglącej konieczności b́riębeŕ blskupich mogło udz1elié trzeoh b1skupón bez zgody innych, zawsze jednak za zgoda prymasa. Osoby zaś przekraczające ten przepis 1 pso faeto mpadaky $\boldsymbol{w}$ ekskomunike ${ }^{13}$. Synody przewidywały tu takze pewien ezozególny przypadek: $\mid$ razie zaistnien1a kłótn1 1 rozdarcia

wáród elektorów podczas myborów kandydata na biskupa, do udzielenta fwiecen biskupioh nie wystarczało trzech biskupó, lecz re mozl1mofol zostall onl zobowiazan1 dołaczy ó do swego grona: jeszeze dwóch lub trzeoh innych biskupón, aby "ten sposób latwiej roz-

8 Ferrandi Carthaginiensis diacont breviatio canonum 11, CCL 149, 288: "Ut ad el1gendum ep1soopun sufficiat matric1s arbitrium".

- Tamze, 2, CCL 149,287: "Ut quicumque la1cus ad episcopatum el1gitur prius annum in ministerio ecclesiastico per omnes gradus transeat'.

10 Conolliu Thelense 1, CCL 149,64/Ex conc1l10 Teleptense/: "Sine sede apostolica id est metropolis nullus ordinetur episcopus [...] plurimorum ep1scoporum"; Ferrandi Carthaginiensis diaconi brev1at1o oanonum 4, CCL 149,287: "Ut ep1seopus a tribus ordinetur, oonsentientibus al118 per scripta, cum confirmatione metropolitani vel primatis".

11 Conollium Thelense 2, CCL 149,61: "Ne unus episcopus episcopum ordinare praesumat propter adrogantiam, ne furtivum beneficium praestitum videatur; hoc enim in synodo Nioaena constat esse deP1nitum".

12 Ferrandi Carthaginiensis diaconi breviatio canonum 4 : nota 10. 13 Concilium Carthaginiense /a. 419/. Canones in eausa Apiari1 12, 
-1azá zarzuty pod adresem wybranego kandydata $1^{*}$ zadá́ juz to osoby wysumajace obiekoje, juz to wage samych zarzutów. Kandydat doplero wówczas mógł byó święcony, jeśl1 został uznany za wolnego od vozelrich oblekcj1 ${ }^{14}$.

Aby na przyszłość wykluczy ó ewentualne kontrowersje, wazysoy nowo kreowanl mieli otrzymác dokument stwierdzający przyjęc1e ́́wieceń, podpisany przez biskupów udzielających św1ęceń, który powinien zawierá dokładna $1 \mathrm{ch}$ date ${ }^{15}$. Przepis ten odnosiz sie do wszystkioh stopni święcen: diakonatu, prezbiteratu 1 biskupstwa.

\section{SPOSOB ZACHOWANIA SIB KLBRU}

1. P r e e d e n f a. Hierarchia kościelna w omawianym przez nas okresie była już stosunkowo dobrze rozbudowana 1 rozwinięta. Dokumenty synodalne podkreślaky jasno nie tylko róznice między poszczególnymi stopniami hierarch11 kościelnej/np. prezbiterem a biskupem/, lecz nawet dystynkeje wewnątrz-jednego 1 tego samego stopnia /np. coetus ep1scoporum/. Wspominani sa na przykład biskup1, którzy zasiadaja na prima sedes, ciesząc się szeroką jurysdykcją 1 wielkim szacunktem. Niekiedy posiadali oni nawet tytuł princeps

CCL 149,121: "[...] S1 vero necessitas fuerit, tres episeopi in quocumque loco sint, eius praecepto ordinare debebunt episcopum. Et s1 qui contra suam professionem vel subscriptionem venerit, 1pse se ab hoo coetu separabit".

14 Reg1stri Eoclesiae Carthaginiensis kixoerpta 50, CCL 149, 188: "[०.] ut quando ad eligendum convenerimus, si qua contradictio fuerit oborta, quia tal1a tractata sunt apud nos, non praesumant ad purgandum eum, qu1 ordinandus est tres $1 \mathrm{am}$, sed postuletur ad numerum supradictorum unus vel duo et in eaden plebe cui ordinandus est discutiantur primo personae contradicentium, postremo etiam 111a quae obiciuntur, pertractentur; et cum purgatus fuerit sub conspectu publico, 1 ta demum ordinetur".

15 Concilium Milevitanum 14, CCL 149,365: "Deinde placuit, ut quicunque deinceps ordinantur iitteras accipiant ab ordinatoribus suis manu eorum subscriptas, continentes consulem et diem, ut nulla altercatio de posterioribus vel anterioribus oriatur". 
sacerdotum lub summus sacerdos. W celu jednak uniknięcia przesady w tym względzie, Jeden z synodów afrykańskich zabrantał uzywá́ tyoh określen ${ }^{16}$.

Synody nakazywały takze posłuszeństwo względem własnych priores. Biskupi wýswięceni wcześniej cieszyli się przywilejem procedencjl. Pierwsze miejsce zarezerwowane było zawsze dla prymasa.' Wszyscy inni biskupi zostall zobowiązani do zasięgania u niego rady co do różnych swołch poczynari. Wóród prymasów zaś pierwsze miejsce zajmowali prymasi Numidil 1 Mauretan11, którzy zawsze cieszyl1 się lus primatis ${ }^{17}$.

2. W y z s z o ś ć k 1 e r u n a d $l$ u d źm 1 ́́ w 1 e k $1 \mathrm{~m}$ 1. Wyżzość duchownych nad śwleck1mi była $\mathbf{w}$ kanonach synodalnych podkreślana bardzo często: cieszyl1 sle ont na przykład przywilejem nietykalności ${ }^{18}$ i nie wolno im było uczęszczá do miejse publicznych /np. do gospód/z wyjątkiem podrózy ${ }^{19}$. Co więcej, nawet dzieci kleru przedstawiane były jako owoistego rodzaju zamknieta grupa. Nie mogły na przykład wykonywać zawodu aktora 1 uozęazczá na widowiska. Zakaz ten miał swoje uzasadniente w tym, iź w teatrach 1 cyrkach przedstawiano bardzo często widowiska niemoralne 1 oparte na wierzentach mitologicznych ${ }^{20}$. Dzieci powinny więc pozostawać pod opiekia rodziców aź do wieku dojrzałego, aby zabezpieczone było ich wychowanie moralne 1 aby ich ewentualne grzechy nie rzutowały

16 Registri Ecolesiae Carthaginiensis Excerpta 39, CCL 149,185: "Ut primae edis episcopus non appelletur princeps sacerdotum aut summus sacerdos aut allquid hulusmodi sed tantum primas sedis episcopus".

17 Concilium Milevitanum 13, CCL 149,365: $n / \ldots . /$ Scimus enim in hac Eeolesia Carthaginiensi inviolate semper permansisse disc1plinam, ita ut nullus fratrum prioribus suis se aliquando auderet anteponere /.../ ut unusquisque nostrum sibi ordinen deeretum adeo oognoseat, ut posteriores anterioribus deferant neo inconsultig primatibus aliquid agere praesumant".

18 Ferrandi Carthaginiensis diaconi breviatio oanonum 139, CCL 149, 299: "Ut non liceat clericum a populo exoomunicari sive praesente sive absente ep1scopon.

19 Breviarium Hipponense 26, CCL 149,40: nUt cleric1 edend1 vel bibendi causa tabernas non 1ngrediantur, nisi peregrinationis neoessitate".

20 Concilium Carthaginiense /a. 419/. Canones in causa Ap1ari1 15, CCL 149,105: "Ut Pili1 sacerdotum spectacula saecularia non 
w sposób negatywny na swiętość stanu duchownego 21 .

Duchownym-poczynajac od stopnia diakona - zakazano zajmowad się sprawam1 świeckimi 1 wykonywá́ świeckie zawody. W ozczególny sposób zabroniono im wykonywanta takich zawod $6 w$, Jak: conductor /osoba wypuszczająca w dzierzawe jakł́ś rzecz materialna/, procurator /admintstrator, dzierzamca/ oraz mszystkie zawody nieszlachetne 22 .

3. D o b r a a t e r i a 1 e. Z analizowanych dekretór synodalnych wynika również wielka troska prawodawoy o ochronę ludzi biednych przed ewentualnaz chciwościa duchownyoh. Dlatego to waśnie wszyscy duchowni, którzy zostali wýfwięcent jako nihil habentes, winni zwrócić Kościołowi wszystkie dobra materialne zakupione podczas wykonywania swojej posługi duszpasterskiej. Jeśli zás tego rodzaju dobra otrzymali od kogoś w spadku, darze lub w inny sposób, winni z nich korzystać w sposób zgodny z godnościa stanu duchownego 23 . Gdy natomiast jakieś dobra zostały ofiarowane poszczególnym Kościolom diecezji, to biskup nie mógł ich zagarną́ dla swojej katedry ${ }^{24}$.

tantum non exhibeant sed nec expectent licet".

21 Breviarium Hipponense 13, CCL 149,37: "Ut episcopi vel cleric1 filios suos a sua potestate per emancipationem exire non sinant, nisi de moribus eorum et de aetate fuerint securi, ut possint ad eos lam propria pertinere peccata".

22 Concilium Carthaginiense /a. 419/. Canones in causa Aplari1 16, CCL 149, 105: "Ut ep1scopi, presbyter1, diaconi non sint conductores aut procuratores neque ullo turpi negotio et inhonesto victum quaerant".

23 Tamże, 32, CCL 149,110: "Item placu1t, ut ep1scopi, presbyter1, diaconi vel quicumque clerici, qui nihil habentes ordinantur et tempore episcopatus vel clericatus sui agros vel quaecumque praedia nomini suo comparant, tamquam rerum dominicarum invasionis orimine teneantur, nisi admoniti in ecclesiam eandem ipsa contulerint. Si autem ipsis proprie aliquid liberalitate alicuius vel successione cognationis obvenerit, faolant inde quod eorum proposito congruit".

24 Ferrandi Carthaginiensis diaconi breviatio canonum 38, CCL 149, 290: "Ut episcopus matrici non usurpet quidquid fuerit donatum ecclesils quae in diocesi constitutae suntn. 
Kanony synodalne zabraniały także klerowi uprawianla lichwy, zaznaczając, iz nie chodzi tu o jakieśs nowe specjalne prawo, ale o przypomienie jej zakazu w Pímie św. 1 w starym prawodawstwie zabraniającym jej osobom świeckim, a tym bardziej duchownym ${ }^{25}$. Przepis ten został późnłej jeszoze bardziej sprecyzowany, gdyż określaz, ze duchowny pożyezający pieniądze, winien odbierać od dzuznika tylko pozyezona lilość pieniędzy 1 to "eadem speciem quantum ei debeturn26.

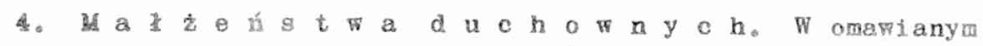
przez nas okresie spotykamy juz w Afryce początki celibatu duchowieństwa. Kanony glosiły, ze swiętym szafarzom przystoi zachowywam ane powścięgliwości zalecanej juz przez Apostozów 1 zachowywanej od czasów starożytnych ${ }^{27}$. W jej notywacji podkreślano więc długa tra-dycję sięgająca czasów Kościoła pierwotnego, to znaczy samych Apostołów. Powścłagliwości tej nie wolno nam jednak pojmować jako zakazu zawierania związków mazżeńskich przez kier. Synody bowiem wymagały jedynie, aby duchowni powstrzymywali sie od stosunków cielesnych ze swolmi zonami 1 żyi z nimi tak, jakby toh nie mieli. Przepls ten jednak dotyozył tylko subdiakonów, diakonów, prezbiterów 1 biskupóm, a inni duchowni nie byli nim wiazani przed osiagnięciem trzydziestego roku życia. Osoby zaś przekraczajace ten nakaz bywały karane suspensqu 28.

25 Concilium Carthaginiense /a. 419/。 Canones in causa Apiarii 5 , CCL 149,102: "Nec omnino cuiquam clexicorum liceat de qualibet re Penus accipere $[. .$.$] Ceterum de quibus apertissime scriptura$ sanxit, non ferenda sententia est sed sequenda. Proinde quod in lalois deprehenditur multo magis debet in clericis praedamnari".

26 Tamże, 16, CCL 149,105: "Ut clericus, si comoodaverit pecuniam, pecuniam accipiat, si speciem, speciem eandem, quantum dederit acclpiat".

27 Tamie, 3, CCL 149,101: "[...] ita placuit, ut condecet sacros antistites ac Del sacerdotes necnon et levitas, vel qui sacramentis divinis inserviunt, continentes esse in omnibus, quo possint simpliciter quod a Domino postulant impetrare, ut quod apostoll docuerunt et ipsa seruavit antiquitas nos quoque custodiamus"。

28 Tamże, 25, CCL 149, 108 109: "Addimus 1taque, Pratres car1ssimi; praeterea, cum de quorumdam clericorum, quamvis lectorum, erga uxores proprias 1ncontinentia referretur, placuit quod et in di-. versis concilis firmatum est: Subdiacones qui sacra mysteria contrectant, diacones, presbyteri, sed et episcopt secundum priora 
Odnośnie do duchownych niższych święceń, przepis ten nie był dokładnie ustalony $i$ praktykowany, gdyż spotykamy równiez kanony głoszace, ze powinni oni zachowywać zwyczaje obowiązujące $1 \mathrm{ch}$ Kościele ${ }^{29}$. Lektorzy na przykład według synodu kartagińskiego z 419 $r$. obowiazani byli ożenté się lub złożyć ślub czystości czy raczej wstrzemięźliwości dopiero po osiagnięciu wieku dojrzałego 30 /należy jednak jeszcze raz przypomnieć, że nie mogli poślubió wdowy/. Co więcej, jak już mówiliśmy, mężczyzna świecki, który poślubił wdowę, nie mogł zostać członkiem kleru ${ }^{31}$.

\section{ZACHOWYWANIE PRAWA}

1. T r y b u n a y yecyzje synodalne ustalały, że duchowni nie mogli procesować się w sądach cywilnych, ale tylko w kościelnych ${ }^{32}$. Trybunał zaś kościelny posiadał stałą, określoną liczbę sędziów, uzaleźnionaz od osoby oskarżonego. W procesie biskupa miało brać udział w charakterze sędziów przynajmniej 12 innych biskupów, a normalnie winno ich byé więcej; w procesie prezbitera - sześciu lub siedmiu biskupów /razem z własnym biskupem prezbitera/; w pro-

statuta etiam ab uxoribus se continere, ut tamquam non habentes videantur esse; quod nisi fecerint, ab ecclesiastico removeantur officio. Ceteros autem clericos ad hoc non cogi, nisi maturiore aetate".

29 Registr1 Eoclesiae Carthaginiensis Excerpta/s. 401/70, CCL 149,201: "Ceteros autem clericos ad hoc non cogi, sed secundum uniuscuiusque ecclestae consuetudinem observari debere".

30 Concilium Carthaginiense /a. 419/. Canones in causa Apiarii 16, CCL 149,105: "Ut lectores, cum ad annum pubertatis pervenerint, cogantur uxores ducere aut continentiam profiteri".

31 Concilium Thelense 4-5, CCL 149,61: "Ut mulierem 1d est viduam clericus non ducat uxorem. Ut is qui laicus viduam duxerit non adinttatur ad clerum".

32 Concilium Carthaginiense /a. 419/. Canones in causa Apiari1 15 a, CCL 149, 137-138: "Item placuit: quisquis episcoporum, presbyterorum et diaconorum seu clericorum cum in ecclesia el fuerit crimen institutum vel civilis causa fuerit commota, si relicto ecclestastico ludicio publicis ludiciis purgari voluerit etiams pro ipso fuerit prolata sententia, locum suum amittat et hoc in criminali: in civili vero perdat quod evicit si locum suum obtinere maluerit". 
cesie zá́ diakona - $\operatorname{trzech}^{33}$. Liczba sędziów nie była jednak dokładnie sprecyzowana, gdyz na przykład $\mathbf{w}$ innym kanonie czytamy, ze sprawe prezbitera winno sądzić pięciu biskupów, a diakona dwóch ${ }^{34}$. Co sie zaś tyozy innych duchownych, to kanony ustalały, ze mieli by 6 sadzent przez Jednego biskupa ${ }^{35}$. Gdy natomiast chodzi o spór z wasnym b1skupem, rozstrzygać go powinni sąsiedni biskupi ${ }^{36}$;

Odnośnie zaś do sporów między duchownymi a laikami, synody postanawiały, ze niewolnicy lub propril liberíni mają być włączeni z liczby os6b mogacych oskarzać duchownych. Do tej l1czby zaliozały osoby pozbawione prawa oskarzania przez prawodawstwo świeckie, a więo te, które były lub są ekskomunikowane, pozostające w stanie Infamil oraz heretyków, pogan 1 Żydów ${ }^{37}$.

2. K a $r$ y. Wiele kanonów mówiących o karach przewidywało takze okskomunike. Polegała ona na wyłaczeniu danej osoby od Eucharyst1i 1 zycia sakramentalnego. Kara ta nie ograniczała sie jedynie do Jakiegoś konkretnego terytorium prowincji kościelnej, lecz rozciągała się na cały Kościół. Z tego tez powodu duchowni ekskomunikowani w swojej własnej prowincji kościelnej nie mogli uczestniczý

33 Tamże, 12, CCL 149, 136-137: "Suggero secundum statuta veterum conciliorum, ut 81 quis ep1scopus, quod non optamus, in reatum al1quem incurrerit et fuerit el nimia necessitas non posse plurimos congregare, ne in crimine remaneat, a XII episoopis audiatur, et presbyter a VI episcop1s cum proprio suo ep1scopo audiatur, ot diaconus a III".

34 Tamze, 20, CCL 149,107.

35 Tamze, "Reliquorum autem olericorum causas etiam solus opiscopus loei cognoscat ot finiat".

36 Conoilium Africanum in Milevitana urbe 22, CCL 149,367: "Item plaoult, ut presbyteri, diaconi vel caeteri inferiores olerioi, In causis quas habuerint, si de ludicils episcoporum suorum questi fuerint, vioint episoopi eos audiant, et inter eos quidquid est finiant adhibiti ab eis ex consensu episcoporum suorum".

37 Concilium Hipponense /a. 427/, 6, CCL 149,252: "Item placult ut omnes servi vel propril libertini ad aocusationem non admittantur, vel omnes quos ad acousanda publica crimina leges publioae non admittunt; neque il qui posteaquam excomunicati fuerint - si In Ipsa adhuc excomunicatione constitutus, sive sit clericus, sive lascus, accusare voluerit; neque omnes infamiae macula adspersi, id est istriones et turpitudinibus sublectae personae, haeretici etiam, sive pagani, sive Iudaei". 
w Eucharystii 1 przyjmować sakramentów św. w innej prowincji ${ }^{38}$. Biskup zá́ lub prezbiter, który by przyjąz osobę ekskomunikowaną do jedności kościelnej, stawał się rómniez winnym ${ }^{39}$.

Wszyscy duchowni uznani za winnych powinnt się starać w clagu jednego roku vykazać swoja niewinność. Jeśli zaś tego nie udało im się dokonać - tracili możnośc unlewinnienta się ${ }^{40}$. Przywraoanie duchownych do jedności kościelnej dokonywało się w inny sposób, niz to miało miejsce w przypadku ludzi śwlecklch 41 .

Najcięźsza karę prawo synodalne przewidywało dla tych, kt6́rzy przyczyniali się do powstania schizm w Kościele. Zarezerwowana była bowiem dla nich anathema 1 nie mogli się spodziewá́ zadnego przywrócenia do jednośc1 z Kościołem ${ }^{42}$.

38 Concilium Africanum in Milevitana urbe 18, CCL 149,366: "Placuit, ut quicunque non communicans in propria provincla in alis provinciis vel in transmarinis partibus ad communicandum obrepserit, iacturam communionis vel clericatus excipiat".

39 Concilium Carthaginiense /s. 419/. Canones in causa Apiari1 9, CCL 149,120: "Augustinus episcopus legatus provinciae Numidiae dixit: Hoc statuere dignemini ut si qui forte merito fac1norum suorum ab ecclesia pulsi sunt et sive ab allquo episcopo aut presbytero fuerint in communione suscepti, etiam ipse pari oum eis crimine teneatur".

40 Reg1stri Ecclesiae Carthaginiensis Excerpta 79, CCL 149, 203204: "L...] si forte causae suae adesse voluerint et innocentiam suam asserere, intra annum excommunicationis hoc paciant. Si vero intra annum causam suam purgare contempserint, nulla eorum vox postea penitus audiatur".

41 Concilium Carthaginiense /a. 419/. Canones in causa Apiari1 32, CCL 149,127: "Confirmatum est ut si quando presbyteri et diaconi in aliqua gravi culpa convicti fuerint, qua eos a rinisterio necesse sit removeri, non eis manus vel tamquam paenitentibus vel tamquam eidelibus laicis imponatur".

42 Tamze, 10, CCL 149,120: "Si qui presbyter a praeposito suo correptus fuerit, debet utique apud vicinos episcopos conventri, ut ab ipsis eius causa possit audiri ac per ipsos suo episcopo reconciliari. Quod nisi feoerit sed superbia magis, quod absit, inflatus secernendum se ab ep1scopi sui communione" duxerit ac separatim cum aliquibus schisma faciens sacrificium Deo obtulerit, anathema habeatur; nihilominus et locum amittat. Et si quaerimoniam iustam adversus episcopum habuerit inquirendum erit". 
IV. TROSKA DUCHOWA O WIERNYCH

1. Trosk a d us z a s t e r s k a o was a t e $r$ y $t$ or $\mathbf{i}$ u m. Wszyscy duchowni, którzy pracowali duszpastersko, mieli zajmować się, zdantem prawa synodalnego tymi wiernymi, dla których zostali wýślęceni. z tego to powodu Inne diecezje nie mogły przyjąć obcego biekupa bez pozwolenia hierarch11 ${ }^{43}$. Przepisy te jednak nie dotyczyły tylko biskupów, bo 1 Inni duchowni nie mogli zmieniac samowolaie swolch dlecezj1. Prawo to obowiązyнało wszystkich członków kleru, poczynajac od lektora ${ }^{4}$. Równiez 1 mnisi nie mogli zmienlac swojego klasztoru ant po to, by stać się członkiem kleru winnym niejscu, ani tez, aby zostać przeorem innego klasztoru ${ }^{45}$. Duchowni więo mogli zmientac smoje diecezje Jedynie za pozwoleniem własnego biskupa ${ }^{46}$.

2. R e z y d e n $\mathrm{j}$ a. Afrykanskie prawo synodalne zobowiazywało duchownyoh nie tylko do nieopuszczania 1 niezmientania swolch diecezji, lecz takze do rezydencji, mając głómnie na wzgledzie dobro duchowe wiernych. Bez pisemnego pozwolenta biskupa duchowny nie mógł udawać się w podróż ani opuszczać miejsca powie43 Registri Ecclesiae Carthaginiensis Excerpta 56, CCL 149, 192-193: pere nisi consensu eius sub quo ruerant constitutae. [0. 7 Non dubito caritati vestrae omium placere eum in diocesi, concedente episcopo, qui matricem tenuit, solam eamdem retinere plebem in qua fuerat ordinatus"; tamze, 48, CCL 149,187: "L..J ut non liceat fieri $[$...J transiationes episcoporum".

44 Concilium Africanum in Milevitana urbe 15, CCL 149,366: "Item placuit, ut quicunque in eoclesia primum vel semel legerit ab alla ecclesia ad clericatum non teneatur".

45 Registri Ecclesiae Carthaginiensis Excerpta 80, CCL 149,204: "Item placuit ut si quis ad alterius monasterio repertum vel ad olericatum vel in suo monasterio maiorem monasteril constituerit episcopus, qui hoc fecerit, a ceterorum communione seiunctus, suae tantum plebis communione contentus sit; et 111 e neque ciericus neque praepositus perseueret".

45 Concilium Carthaginiense Tertium/a. 435/, 21, CCL 149,333: "Ut clericum alienum, nisi concedente eius episcopo, nemo audeat retinere vel promovere in ecclesia sibi credita". 
rzonego jego trosce 47 . Co więcej, nawet samt biskupi nie mogli podrózować bez pozwolenta prymasa prowincji. Przepis ten jednak obowlazywał 1ch tylko wtedy, gdy zamierzali udać sie w dalsza podróz / trans mare/ ${ }^{48}$. Zawgze jednak winni pamiętać o tym, aby z tego powodu nte ucierpiało zlecone im duszpasterstwo. Dlatego tez na przykład nie mogli udać się nawet do jakiegó́ kościoła swojej diecezjl, gdyby przez to zaniedbywall wasną katedrę ${ }^{49}$.

$$
\text { 3. "P } r \text { o } 1 \text { z j a } k \text { a } n \circ n 1 \text { c } n a " \text {. W omawianym }
$$

przez nas okresie podczas wyborón biskupa byl1 w Apryce obecni także 1 ludzie śwlecoy. Miejsce jednak naczelne 1 najwaźniejsze ze wszystkich zajmował duchowny zwany interventor. Był nim przewaznie biskup, który pełnił tę Punkeję ozagowo $i$ opiekował się diecezją pozbawionq okresowo duszpasterza. Miał on obowiazek zebrać wiernych na wybory biskupa "ut ep1scopum acciplant". Jeáli jednak wybór nowego duszpasterza przeciągał się ze vzględu na lenistwo wiernych, interventor/zwany czasem intercessor/ bywał odwoływany, a lud pozostawał bez ordynariusza az do czasu poproszenta o biskupa ${ }^{50}$. Kara ta miała na celu pobudzenie lentwych wiernych do szybkiego wyboru nowego biskupa, a jej groźba została dodana do kanonu jako wyraz gor1iwośc1 pastoralnej prawodawcy. Inny znów kanon zachęcal samego interventora, aby nie zwlekał z wyborem nowego biskupa lub teź sam

47. Conc1ilum Africanum in Milevitana urbe 20, CCL 149, 366-367: "Plaouit, ut quicunque clericus propter necessitatem suam alicubi ad comitatum iro voluerit, formatam ab episcopo suo accipiat : qui sine formata voluerit pergere, a communione removeatur"; Ferrand1" Carthaginiensis diaconi breviatio canonum 127, CCL 149, 298: "Ut clerici sine Pormata êt conscientia episcopi per alienas plebes non vagentur"。

48 Breviarium Eipponense 27a, CCL 149,41: "Ut episoopi trans mare non proficiscantur, nisi consulto primae sedis episcopo suae culusque provinciae, ut ab eo praecipue possint Pormatas accipere".

49 Registri Ecclesiae Carthaginiensis Bxeerpta 71, CCL 149,201: "Rursum placuit ut nemini sit facultas relicta principali cathedra, ad aliquam ecclesiam in diocesi constitutam se conferre, vel in re propria diutius quam oportet constitutum, curam vel frequentationem propriae cathedrae neglegeren.

50 Ferrandi Carthaginiensis diaconi breviatio canonum 23, CCL 149, 289: "Ut interventores episcopi conveniant plebes, quae episcopum non habent, ut ep1scopum acciplant; quod si accipere neglexerint, remoto interventore, sic remaneant, quamdiu sibi episcopum quaerant". 
obją diecezje, w której sprawował tę Punkcję, z zaznaczeniem, iz nowy biskup ma być wybrany w ciągu jednego roku. Jeśli po upływie tego czasu nie wybrano biskupa, interventora odwoływano, a na jego miejsce przychodził inny ${ }^{51}$. Kanony ustalały, że do wyboru biskupa wystarczała decyzja Kościoła-Matki Matrix/52.

W kanonach synodalnych spotykamy także zastrzeżente, aby nie przyjmować duchownych usuniętych z innych diecezji, gdyz nie mogli oni pracować duszpastersko. Także $i$ ten przepis został wydany po to, aby bronić wiernych przed złymi pasterzami 53 .

4. U d z 1 - 1 a n 1 e a k r a m e t ó w. Zauważamy, ze w omawianym przez nas okresie obrzędy sakramentów św. przyjmowały stała 1 określoną forme. Synody nakazywały ujednolicenie rytów 1 modlitw liturgicznych a szafarze sakramentów zobowiązani zostali do używania jedynie modlitw 1 ryt6w przez nie zaaprobowanych ${ }^{54}$.

Zwyczaj chrzczenia dzieci by $ł$ juz znany $i$ rozpowszechniony. Owszem, lstniał nawet synodalny nakaz, że jeśli przypadkiem znalazłoby sie jakieś dziecko, co do którego zachodziłaby wątpliwość, czy jest ochrzczone, należało je bez skrupułóm ochrzcic ${ }^{55}$. Troszczono sie również, aby chorzy, którzy nie zostali jeszcze ochrzczeni, przyjęli ten sakrament ${ }^{56}$. Zabraniano jednak udzielania sakramentów

51 Registri Ecclesiae Carthaginiensis Excerpta 74, CCL 149,202: "Constitutum est ut nulli intercessori licitum'sit cathedram, cui intercessor datus est, quibuslibet populorum studis vel seditionibus retinere, sed dare operam ut intra annum eisdem episcopum provideat. Quod si neglexerit, anno exempto, interventor alius tribuatur"

52 Ferrand Carthagintensis diacont breviatio canonum 11, CCL 149, 288: "Ut ad eligendum episcopum sufficiat matricis arbitrium".

53 Concillum Thelense /a. 418/, 7, CCL 149,61: "Ut abiectum clericum alla eoclesia non admittat".

54 Ferrandi Carthaginiensis diaconi breviatio canonum 220, CCL 149,305: "Ut una sit in sacramentis per omne Byzacium disciplina".

55 Breviarium Hipponense /Concilium Carthaginiense a. 401/, 39, CCL 149,46: "Item placult de infantibus, quoties non inveniuntur certissimi testes qui eos baptizatos esse sine dubitatione testentur [...] absque ullo scrupulo eos esse baptizandos, ne tsta trepidatio eos faciat saoramentorum purgatione privari".

56 Breviarıum Hipponense 32, CCL 149,42: "Ut aegrotantes, s1 pro se respondere non possúnt, cum voluntatis eorum testimontum sui 
\{́w. zmarłym, jak: powtórnego chrztu, Eucharystil, czy swięoen ${ }^{57}$. Co się zaś tyczy bierzmowania, nie moglo oyć ono udzielane przez prezbiterów, leez zarezerwowane byto tylko biskupom ${ }^{58}$. Eucharystia była sprawowana przez szafarzy na czczol wyjatek stanowil tu Wielki. Czwartek), co niewątpliwie wpłynęio na stopniowe zanikanie Mszy św. wieczorowych 59 .

Odnośnie zaś do pokuty należy powledzleć, że długość jej trwania była ustaiona przez biskupa i zależała od rodzaju grzechów popełnionych przez penitenta. Także sam moment pojednania penitentór zarezerwowany by biskupowi, a prezbiter bez jego pozwolenia nie

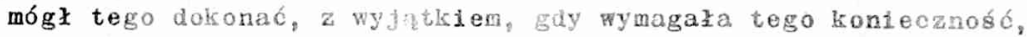
a biskup byt nieobecry. Jé́lt zaś chodzizo o penitenta, którego grzech był publiczny i baxdzo zaszkodził Kościołowi, to miaz on być pojednany ante absidam przez wlozenie ręk1 bıskupa, gdyż prezbiterowi, jak juz wspominaliśmy, nie wolno było tego czynić 60 。 Pojednanie chorych takze zarezerwowane by $\mathbf{l} 0$ biskupowi. Gdy jednak ci chorzy znajclowall sie in periculo mortis, a biskup byl nieobecny, ich pojednania mógz dokoná́ prezbiter, skonsultowawszy się z biskupem. Konsultaoja ta była prawdopodobnie rozumiana jako relaoja zdana przez prezbitera biskupowi po zaistnialym fakcie. Nie byłe to

periculo proprio dixerint, baptizentur".

57 Conciliun Carthaginiense/a.418/. Canones in causa Apiarii 18be, CCL 149,139: "Item placult ut corporibus defunctorum eucharistia non detur: scriptum est enim: "accipite et edite" cadavera autem nec accipere possunt nec edere. Et ne iam mortuos homines baptizari faciat presbyterorum ignavia".

58 Concilium Carthaginiense /a. 390/, 3, CCL 149,13: "L.. $7 \mathrm{nam}$ me mini praeteritis concilis fuisse statutum, ut chrisma vel reconciliatio paenitentium, necnon et puellarum consecratio a presbyterios non fiat".

59 Breviarlum Hipponense 28, CCL 149,41: "Ut sacramenta altaris nonnisia leiunis hominibus celebrentur, excepto uno die amiversario quo Cena Domini celebratur. Nan 81 allquorum postmeridiano tempore defunctorum $[\mathrm{*} \cdot \mathbf{J}$ commendatio lacienda est, solis orationibus iiat, si ilii qui paciunt iam pransi inuendantur"

60 Concilium Carthaginiense /a.397/, 43abo, CCL 149,185: "vt paenitentibus, secundum differentiam pecoatorum, episcopi arbitrio, paenitentiae tempora decernantur. Et ut presbyter, 1 nconsulto episcopo, non reconciliet paenitenten, nisi absentia emiscopt. necessitate cogente. Cuíscumque autem paenitentis pubilcum et vulgatissimum crimen est, quod universam ecclesiam commoverit, ante absidam manus ei imponatu". 
Jednak sprawa zbyt Jasna, gdyż kanon postanawiaz, iż prezbiter:

"debet consulere episcopum et sic periclitantem e 1 u s p r a e c e t o reconciliaren ${ }^{61}$.

5. T r o s a 0 d z $i$ e w i c e 1 w d o w y. Dziewice 1 wdowy tworzyły w Kościele dwa stany, z których pierwszy uważany był za stan wyższy. Aby móc doń należeć, trzeba było przyjąć specjalną konsekrację, której udzielente zarezerwowane było biskupowi. Prezbiter nie mógł jej nigdy udzielí $6^{62}$. Nazywano ją przewaznie velatio, gdyz jej znakiem widzialnym było włozenie na głowe dziewicy welonu. Mogła ona być udzielona jedynie wówczas, gdy dzı ewczyna osiągnęła juz 25 lat, choć zdarzało sį̊, że udzielano jej takze wcześniej, gdy czystość danej dziewicy była zagrożona ${ }^{63}$.

Swięte dziewice mogły mieszkać razem z rodzicami, ale nigdy same. Z tej to racji, jeśll nie miały rodziców, biskup, a tam, gdzie nie było biskupa, prezbiter, zobowiązany był do oddania loh pod opieke szanowanych niewiast w celu uchronienia $1 \mathrm{ch}$ czystości, a co za tym idzie - dobrej sławy Kościoła ${ }^{64}$.Co więcej, aby n1e naraźá Kościoła na zniesławienie, zabroniono duchownym odwiedzania samotnych wdow 1 dzlewic bez pozwolenia biskupa lub prezbitera. Sami zas biskupl lub prezbiterzy mogli je odwiedzać tylko w towarzystwie duchownych lub chrzéscijan c1eszących się szacunkiem ${ }^{65}$.

6. W a 1 k a z p o g a b $\mathrm{z}$ w e m. Prawodawstwo synodalne troszczyło się również o ochronę wiernych przed pogańskimi

61 Concilium Carthaginiense /a, 390/, 4, CCL 149,14.

62 Tamże, 3, CCL $149,13: " \angle \ldots J$ necnon et ut pueilarum consecratio a presbyteris non plat".

63 Registr1 Ecclesiae Carthaginiensis Excerpta/Conc. Carthag. a.t418/, $126 \mathrm{CCL}, 149,227$ : "Item placult, ut quicumque episcoporum, necessitate periclitantis pudicitiae virginalis, cum vel petitor potens, vel raptor aliquis formidatur, vel si etiam allquo mortis periculoso scrupulo compuncta fuerit ne non velata moriatur. aut exigentibus parentibus aut his ad quorum curam pertinet, velaverit virginem seu velavit intra viginti et quinque annos aetatis, non ei obsit concilium quod de isto annorum numero constitutum est".

64 Breviarium H1pponens 31, CCL 149,42: "Ut virgines sacrae, cum parentibus a quibus custodiebantur privatae fuerint, episcopi vel presbyteri, ubi episcopus absens est, providentia gravioribus feminis commendentur, aut simul habitantes invioem se custodiant, ne passim ragando eoclesiae laedant existimationem". Tamze, 24, CCL 149,40: "Ut clerie1 continentes ad viduas vel 
wpływant. Pontewaz zaś poganie nie byl1 zobowiazani do posłuszeństwa kanonom kościelnym, synody ządały od cesarzy wydania nakazu zburzenia wszystkich pogańskich resztek, bałwanów 1 1ch świątýn - Afryce nie przedstawiajacych jednak zadnej wartośc1 artystycznej $^{66}$ I zakazu praktyk1 takich zwyczajów pogańskich, jak: śmięte uczty urządzane szozególnie w święta męczenników, tańce rytualne, spektakle teatralne, 1grzyska cyrkowe 1 gry publiczne organizowane przewaźnie w dni świąteczne lub w niedziele, szczególnie podczas oktawy wielkanocnej, które pociągały wiernych bardziej niz kościo$1 y^{67}$.

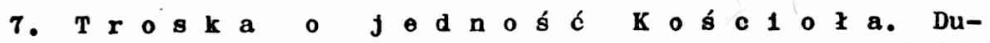
ohowni, a zwaszcza biskupi, winni si z także troszczyć o jedność Kośc1oła, czyniąc wszystko, co tylkow ich mocy, aby wednej Owczarni Chrystusowej zgromadzić tych wszystkich, którzy się poza nią znajdują. Jeśli zaś któryó z biskupów nie czynił tego, winten być do tej działalności pabudzony. Gdy natomiast w przecizgu sześciu miesięcy nie zmienił swego postępowania, mogli tę akcję poprowadzić

virgines nisi ex lussu vel permissu episcoporum vel presbyterorum non acoedant; et hoc non soli faciant, sed cum clericis aut cum his cum quibus episcopus aut presbyter iusserit. Sed nec 1psi episcopi aut presbyteri sol1 habeant accessum ad huiusmodi reminas, sed aut ubi cleric1 praesentes sunt aut graves allqui ohristiani".

66 Registri Eoclesiae Carthaginiensis Excerpta/Con. Carthag. a. 401/, 58, CCL 149,196: "Instant etiam aliae necessitates a religiosis imperatoribus postulandae: ut religuias idolorum per omnem Africam lubeant penitus amputari $[. . J$ ut praecipiantur et Ipsa deleri, et templa eorum, quae in agris vel in locis abditis constituta, nullo ornamento sunt, iubeantur omnimodo destrui".

67 Tamże, 60-61, CCL 149, 196-197: "Illud etiam petendum ut, quoniam contra praecepta divina convivia multis in locis exercentur, qua ab errore gentill adtracta sunt [...] vetari talia lubeant $[. .$.$] maxime cum etiam in natalibus beatissimorum mar-$ tyrum per nonnullas civitates et in ipses locis sacris talia commitere non reformident [...]. Necnon et tllud petendum, ut spectacula theatrorum ceterorumque ludorum die dominica vel ceteris religionis christianae diebus celeberrimis amoveantur; maxime quia sanctae paschae octavarum die populi ad circum magis quam ad ecclesiam conveniunt $[\ldots .]^{\prime \prime}$ 
sąsiednt biskup1, a pozyskanych do jedności z Kościołem katolick1m nawet przyłącáć do swoich diecezj1; leniwy zaś biskup winien byé surowo ukarany ${ }^{68}$. Odnó́nie do heretyków lub schizmatyków synody zaohęcały, by postępować z niml lenter et pacifice ${ }^{69}$. W oparciu o powyzsze decyzje mogli byé przyjmowant do Koścloła katolickiego nawet pragnący jednośc1 duchown1 donatyst $6 w^{70}$. Jeden z dotyczących tej sprawy kanonów nakazywał, aby biskup zarządził modlitwy podczas trwanta procesu przeciw heretykon $w$ trybunale cywilnym. Wynika wieo z tego, ze nie tylko biskupi, ale wszyscy ozłonkowie Kościoła miell troszczy é się o jego jednośc ${ }^{71}$.

\section{TROSKA O DOBRA MATERIALNE KOSCIOLA}

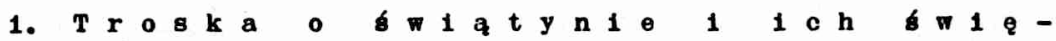
t o s. Kanony synodalne Afryki podkréllaky rowniez troske o obronę przed profanacja obiektów sakralnych 1 o zapewniente świętósci miejscom f́więtym. Swiątynia jest miejscem świętym, wyjętym spod ozynnoścl f́wlecklch 1 winna byé użyana wylacznie dla kultu. Zarówno więc duchowni, jak 1 świeccy musieli respektowaé jej b́więtó́b.

68 Registri Eeclesiae Carthaginiensis Excerpta/Conc. Carthag. a. $418 /$, 121, CCL 149,226: "Item placuit ut quioumque neglegunt loca, ad suam cathedram pertinentia, in catholicam unitatem luorari, conveniantur a diligentibus vioinis episcopis, ut id agere non morentur. Quod si intra sex menses a die conventionis non effecerint, qui potuerit ea lucrari, ad ipsum pertineant".

69 Registri Eeclesiae Carthaginiensis Excerpta/Conc. Carthag. a. $401 /, 66$, CCL 149,199 .

70 Tamze, 68, CCL 149,200: "De1nde placuit $/ \ldots .7$ propter occlesiae paoem et utilitatem: ut ex 1psis Donatiotis, quicumque cleriol, correoto consilio, ad catholicam unitatem transire veluerint, ceoundum uniuseuiusque eplscop1 eatholiol voluntaten atque conc1lium, qui in eodem loeo gubernat ecolesiam, 1 hoo paed ecelo- Lae prodesse visum fuerit, in suis honoribus susoipiantur".

71 Ferrand1 Carthaginiensis diaconi breviatio eanonum 44, CCL 149, 291: "Ut liceat unioulque episcopo procuratores constituere, quando de ludicis publicis contra haereticos allquid est petendum". 
Jedynie w przypadku konieczności /np. dla pielgrzymów/mogła byé wykorzystana dla celow 6 w1eok1ch ${ }^{72}$.

2. A 11 e n e f a 1 p r a d a z. Synody nakazywały duchownym, aby zachowali stan posiadania 1 strzegli dóbr materlalnych Kościoła, zabraniając Im przy tym dokonywania alienaoji 1 sprzedazy. Wszyscy duchown1 zobowlązan1 byl1 do zachowanta patrimonium materialnego Kościoła: biskupi nle mogli sprzedawać dóbr materialnych bez pozwolenta synodu lub prymasa, czy tez wszystkioh prezbiterów, prezbiterzy zaś bez pozwolenia biskupa ${ }^{73}$. Tszysey jednak mogli tego dokonywać jedynie w przypadku kontecznośc1 lub gdy Kościół nie miał odpowiednich dochodów. Jeśl1 wypadku naglacej koniecznośc1 zabrakło czasu, aby zwrócté się o zezwolente do prymasa lub synodu, wystarczyło zasiegnięcie opinii sąsiednich biskupów, zawsze jednak z intencją późniejezego powiadomienia o wszystkim synodu. Biskupl, którzy przekraczal1 to prawo, byli uwazani za grzeszników 1 osoby podległe infami1 ${ }^{74}$. Kanony synodalne zabraniały nie tylko sprzedaży dóbr materialnych, lecz takze przenoszenia $1 \mathrm{ch}$ bez pozwolenia. Również w tym przypadku osoby lekcewaźce to prawo uważane były za winne w takiej samej mierze jak złodzieje ${ }^{75}$.

72 Breviarium Hipponense 29, CCL 149,41: "Ut null1 episcop1 vel clerici in ecclesia conviventur, nisi forte transeuntes hospit1orum necessitate 1llic reficiant; populi etiam ab hulusmodi convivils, quantum potest fieri, prohibeantur".

73 Concilium Carthaginiense /a. 419/. Canones in causa Apiari1 33, CCL 149, 110-111: "Ita et1ain placuit ut presbyteri non vendant rem ecciesiae ubi sunt constituti, nescientibus episcopis, quomodo episcopis non licet vendere praedia ecclesiae, ignorante concilio vel presbyteris suis, non habentes necessitatem"; Ferrandi Carthaginiensis diaconi breviatio canonum 47 , CCL 149,291: "Ut episcopi rem ecclesiae sine primatis consilio non vendant".

74 Concilium Carthaginiense /a. 419/. Canones in causa Apiari1 26, CCL 149,109: "Placuit etiam: Ut rem ecclesiae nemo vendat; quod si reditum non habet, et aliqua necessitas nimia cogit, hanc insinuandam esse primati provinciae ipsius, ut cum statuto numero episcoporum utrum faciendum sit arbitrentur. Quod si tanta urguet necessitas ut non possit ante consulere, saltim vicinos testes convocet ep1scopos, curans ad concilium omne referre suae ecclesiae necessitates. Quod si non fecerit, reus Deo et conci110 venditor, honore amisso, teneatur".

75 Concilium Hipponense /a. 427/, 4, CCL 149,251: "Item placuit ut episcopi sive presbyteri, ea quae sunt in locis ubi ordinantur si ad alia loca dederint, causas praesentent, vel episcop1 suis concilis, vel clerici episcopis suis; et si nullas lustas ha- 
3. D a r o 1 z $\mathrm{n}$ y. W selu zachowania patrimonium Kościola katolicklego, prawa synodalne zabrantały dokonywanla jakiejkolwiek dotacji na rzecz akatolikóm. Wszyscy duchowni byl1 zobowiazani do niedawania niczego nikomu, nawet swoim krewnym. Nie chodzi tu jedynte o dobra kościelne, lecz także o prywatne ${ }^{76}$. Kary na przekraozajacych poryższe prawa by ky bardzo surowe: mieli by ekskomunikowani 1 - jako tacy - niewymientani wyptyohach ${ }^{77}$.

\section{SYNODY}

Odwołując się do dekretu Soboru w Nicei, synod kartagiński z 419 r. nakazal zwoływanie synodów kaźdego roku. Mieli w nich uczestniczyć reprezentanci wybrani z poszczególnych prowincji/przynajmniej dwóch z prowinoj1, z Tripolis zaś - ze względu na małość tej prowincj1 - przynajmniej jeden biskup ${ }^{78}$. Wszyscy biskupi wezwa-

buerint causas, sic in eos vindicetur, tamquam in furto fuerint deprehensi".

76 Breviarium Hipponense 14, CCL 149,37: "Ut episcopi vel cleric1 eis qui christiani cathoilci non sunt, etiamsi consanguine1 fuerint, noo per donationes rerum suarum aliquid conferant".

77 Registri busiesiae Carthaginiensis Bxcerpta/Conc. Carthag. a. 101/, 81, CCL 149,204: "Item constitutum est ut si quis episcopus haeredes extraneos a consanguinitate sua vel haereticos -t1am consanguineos aut paganos ecolesiae praetulerit, saltem post mortem anathema el dicatur, atque eius nomen inter Dei sacerdotes nullo modo recitetur".

78 Cone1lium Carthaginiense/a. 419/. Canones in causa Ap1aril 18 d, CCL 149, 139-140: "Pro qua re confirmandum est in hac sanota synodo ut ecundum Nicaena statuta propter causas ecclesiasticas quae ad perniciem plebium saepe veterascunt singulis quibusque annis concilium convocetur ad quod omnes provinciae quae primas sedes habent de concilils suis binos aut quantos delegerint ep1soopos legatos mittant ut in congregato conventu plena posit esse auctoritas"; Breviarium Hipponense 5 b, CCL 149,34: "De Tripoli vero, propter inopiam episcoporum, unus episcopus veniat". 
n1 na synod zobowiazani byli do czynnego wim udziału. Wyjatek stanowili starcy, którzy nie mogli sie poruszać oraz osoby chore. C1, którzy przekraczali ten przepls, mieli być ekskomunikowani ${ }^{79}$. Same synody podkreślały, iź promulgowane przez nie kanony winny być przestrzegane przez wszystkich duchownych 1 świeckioh ${ }^{80}$.

$$
\text { 0. Bazyl1 Degórski OSPPE - Rzym }
$$

\section{QUID DE CLERICIS SYNODI AFRICAE IV ET V SABCULI STATUERINT? /Argumentum/}

Hac in dissertatiuncula exponuntur ea, quae de oleriols synodi Afrioae IV et $V$ saecul1 statuerunt. In partioulari auten traotatur de ordinationibus saoerdotallbus, de modo vitas ao matrimonio clericorum, de eorum relatione ad leges ecclesiasticas ao civiles, de cura pastoral1 exeroenda ac sacramentorum administratione et densque de clericali diligentia erga aedificia ac bona materialia $\mathrm{B}$ Boclesiae.

79 Ferrandi Carthaginiensis diaconi breviatio canonum 76, CCL 149, 293: "Ut exceptis senibus qui loco moveri non possunt et infirmis episcopis, qui admonitus ad concilium non occurrerit, communione privetur".

80 Tamze, 218, CCL 149,305: "Ut concillorum statuta priscorum ab omnibus observentur". 